\title{
RED APPLE
}


This page intentionally left blank 


\section{RED APPLE COMMUNISM AND MCGARTHYISM IN GOLD WAR NEW YORK}

\section{PHILLIP DEERY}

Empire State Editions

An imprint of Fordham University Press

ESE New York 2014 
Copyright (C) 2014 Fordham University Press

All rights reserved. No part of this publication may be reproduced, stored in a retrieval system, or transmitted in any form or by any means-electronic, mechanical, photocopy, recording, or any other-except for brief quotations in printed reviews, without the prior permission of the publisher.

Fordham University Press has no responsibility for the persistence or accuracy of URLs for external or third-party Internet websites referred to in this publication and does not guarantee that any content on such websites is, or will remain, accurate or appropriate.

Fordham University Press also publishes its books in a variety of electronic formats. Some content that appears in print may not be available in electronic books.

Library of Congress Cataloging-in-Publication Data

Deery, Phillip.

Red apple : communism and McCarthyism in cold war New York / Phillip Deery.

pages $\mathrm{cm}$

Includes bibliographical references and index.

ISBN 978-0-8232-5368-5 (hardback)

1. Anti-communist movements-New York (State)-New York-History20th century. 2. Political persecution-New York (State)-New YorkHistory-20th century. 3. Anti-communist movements-United StatesHistory - 20th century. 4. Political persecution-United States-History20th century. 5. Joint Anti-Fascist Refugee Committee. 6. United States. Congress. House. Committee on Un-American Activities. 7. New York (N.Y.) - History-20th century. I. Title.

E743.5.D374 2014

$974.7^{\prime} 043-\mathrm{dc} 23$

Printed in the United States of America

$\begin{array}{lllllll}16 & 15 & 14 & 5 & 4 & 3 & 2\end{array}$

First edition 
For my sons, David and Michael 
This page intentionally left blank 